\title{
Quiz Learning Modelling: In the Development of Thematic Learning on Distance Education Module
}

\author{
Suhartono $^{1, *}$, Benedicta Esti Pramuki ${ }^{1}$, Bunyamin Mafhtuh ${ }^{2}$, Nana Supriatna ${ }^{2}$ \\ ${ }^{1}$ Faculty of Education and Teacher Training, Universitas Terbuka, Indonesia \\ ${ }^{2}$ Program Pascasarjana, Universitas Pendidikan Indonesia, Indonesia
}

Copyright $(2019$ by authors, all rights reserved. Authors agree that this article remains permanently open access under the terms of the Creative Commons Attribution License 4.0 International License

\begin{abstract}
This study analyzed the quality of teaching materials to improve the competence of students and to provide innovation in the development of interactive modules, which are varied by enacting quizzes as an interactive medium textbook in Distance Education. The research method was developed through three steps of research, namely the preliminary study phase, the trial of one on one with three students, and test a small group (small group) with ten students. The application was based on a learning approach as a system (input - process output) which consists of several inter-functioned components to achieve goals regarding the model to generate the design - implementation - evaluation and follow-up. This research was conducted at the Open University of Indonesia by involving students, lecturers/ tutors in the PGSD study program and experts. The results showed: an improved exercise in the module includes five categories of the need for students to enrichment training, compliance with the depth and breadth of training materials, the pattern of interactive exercises, the language used and exercise equipped. Based on the results of the student questionnaire, it was known that the model exercise/quiz was developed accordingly. So, Teachers/ Students can take advantage of this type of exercise/ quiz as an alternative mastery of the material.
\end{abstract}

Keywords Thematic Learning, Module, Quiz, Distance Education

\section{Introduction}

Universitas Terbuka (UT) is Open University operated in Indonesia. As a Long Distance Learning System, UT exhibits a significant difference from a conventional university. UT student is required to learn independently, without direct face to face interaction with their tutors [1, 2]. For such purpose, UT provides teaching materials explicitly designed in order to enable students who study the teaching materials feel like in a dialogue with the tutors. Therefore, UT teaching materials should be communicative, interactive, and oriented towards the interests of students' learning.

Julaeha and Pratmoko [3] stated that the primary teaching material used at Terbuka University are printed teaching materials, called modules, which were designed specifically and enabled students to learn based on their respective abilities. The development of good distance learning materials needs to involve elements that can provide improvement for the module section, such as from experts whether for material, media, language, graphic design, lecturers or tutors and students who ultimately make a Basic Material Book (BMP) have excellent quality. These various inputs and evaluations are instrumental in obtaining information for the "shortcomings" of previous teaching materials. Furthermore, this information can be used as a basis for revising the teaching materials.

In the fulfillment of independent learning that must be applied by distance education students, there is a need for teaching material that also has characteristics for independent learning needs. Review print materials (modules) as learning media. According to Ellington [4], printed teaching materials are teaching materials designed in simple, communicative, and clear language, which can involve student' thinking processes, and can evaluate the level of students' mastery of the independent learning process.

Referring to the concept of ideal characteristic of learning material mentioned above, UT's teaching material is considered good; if only it meets the prerequisite standards, the contents are up-to-date, and the students can quickly learn it $[5,6]$. For such purpose, UT has published guidelines on how to develop excellent learning material's content and presentation. The construction of learning materials is written based on the Prescribed Course Design Plan, which consists of Competences Analysist and Teaching Program Outlines. There are two primary criteria for good module: the up-to-date content and the easy-to-learn by distance learning students. The contents of 
the module should not be out of date. Whether the material is easy to learn by students or not is based on the achievement of students' learning evaluation at the end of the program.

To keep the quality of UT's teaching materials, the tutors at UT need to evaluate their modules. The evaluation involved getting feedback from experts on learning media, language expert, graphic designer, peer tutors, and students, in order to create excellent Primary Source Books. Various input and evaluation are instrumental in obtaining information on the "shortage" of the modules. Furthermore, this information serves as a basis for revising instructional materials. Teaching materials innovations efforts are developed so that the Primary Source Books is more varied in presentation and teaching materials that can foster self-reliance and sense of fun of the student to learn the MMB. Researchers will develop a model of interactive learning through a quiz on each dish on the training module. The importance of research by focusing on development exercises/quizzes on the interactive and varied module is to help students understand the material available in the module and become a bridge in honing students' ability to master various concepts.

The problems of development of teaching materials focused on answering questions about: what type of quiz in every module that is interactive and varied to improve students' ability to achieve the expected competencies. The purpose of this research is to identify instructional materials models and improve the quality of teaching materials to pack the exercises/quiz on the module more interactive and varied as teaching materials of Long Distance Education at the Open University of Indonesia.

\section{Systematical Review}

\subsection{Interactive Exercise/Quiz Model and Variation in Module}

Complexity, the uniqueness of the learning process, the accuracy of media selection, and learning methods will significantly affect the student learning outcomes [7-9]. Also, students will influence their perceptions of learning outcomes $[10,11]$. Therefore, the selection of media should pay attention to the complexity and uniqueness of the learning process, understand the meaning of perception, and the factors that influence the perception of explanation should be sought optimally so that the learning process can be done effectively.

\subsection{The Power of Exercise/Quiz as an Essential Component in Module}

The meaning of exercise in teaching and learning relationship is an action/act of repetition that aims to enhance learning outcomes [12]. Stabilization is as ongoing improvements and the expansion attempts. Exercise can be an individual process and may also be a process of the group [13].

By setting the learning goals, the direction of the learning will be visible, and run effectively and efficiently. Morrison, Ross, Kalman and Kemp [14] cite exercise or quiz as a critical component in the module with the elaboration as follows:

- Learning Indicators. Learning guidance or instruction set similar to the set of indicator in the instrument test. Indicators should be described clearly on what to do and how to do it [15]. The primary consideration used in the instruction set is the expected behavior of the learning objectives and procedures to be followed to achieve the learning objectives.

- Description of activity and exercise. The learning activities should be planned carefully and lead directly to the achievement of learning goals. In establishing guidance to a range of activities and exercise activities sometimes it gave the options so the learner can choose the preferred method [14].

- List of Sources. If there is trouble, then students can be directed to read the source or reference related to the matter. They can also be directed to read library books, reading resources from the mass media, and so on [14]. Morrison also suggests that activity and the source should be selected appropriately and regularly refers to the achievement of learning goals.

The effectiveness of an exercise depends on the quantity of the materials. A bunch of material takes too much time. If the substance is not meaningful, it will take a longer time to exercise. On the other hand, if the material is not too much to learn and also the material is meaningful, the exercise time is reduced, and the result of exercise will be better. Distribution of exercise influences the effectiveness of exercise programs. There are two types of distribution of exercise: massed practice and distributed practice. Type distribution was done depending on certain conditions. In massed practice, the rest time is shorter in order not to forget and laborious. Therefore, this exercise requires long periods.

\section{Research Method}

Evaluation of the quiz component in students' learning material is based on the print workbook and module content characteristics. It should maintain its relevancy and consistency between the components contained in the exercise module material. Researchers focused on the development of exercise's interactive and variations in the module. The development method used is a guidance document analysis using questionnaires, interviews, and observations that have been designed by researchers. 


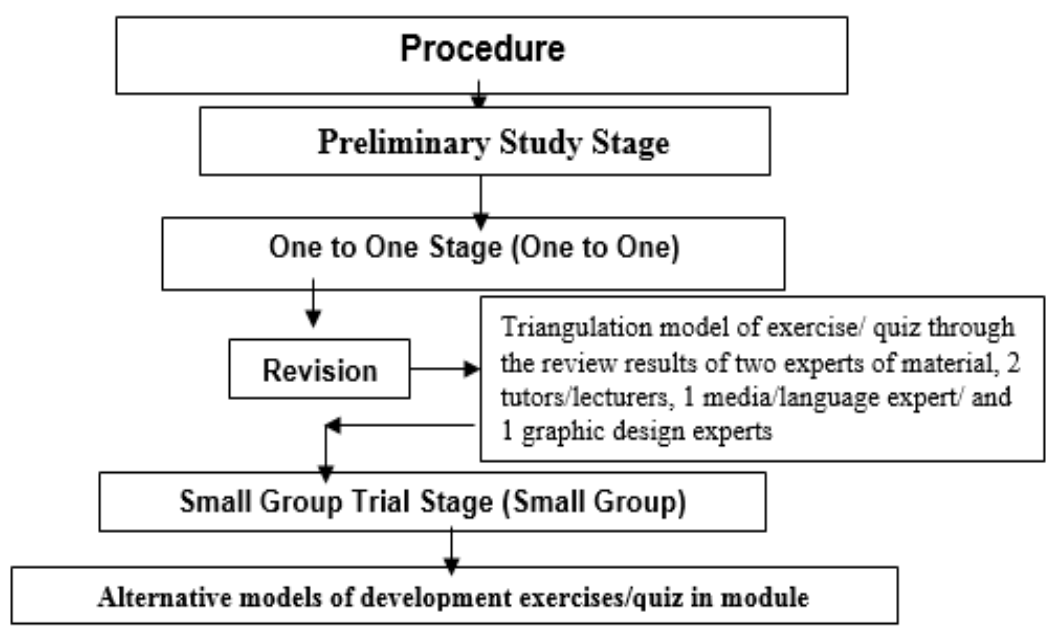

Figure 1. Visualization of the Flow of Research Procedure

The object of the research is the Primary Resource Book Basic Concepts IPS PDGK4102 course code. Components of the material learning evaluated focused on the analysis of the exercise/quiz model that is interactive and varied in modules 1 and 4 . The Elections to the three modules based on the results of teaching materials research in 2014 showed that the student assesses the modules has the characteristics of the material elusive because it consists of understanding the basic concepts of Social Studies. Time series on the development of the idea of history, the model design, and implement basic skills in Integrated Social Science. The Implementation of the research was conducted in June-December 2016 until one to one evaluation stage and small group.

Reflection only implemented at the preliminary phase. The Reflection Analysis stage involves seven people consisting of students, staff and experts. In one to one phase, there were 3 PGSD undergraduate evaluators. At the material analysis phase, the Material Expert involved two material experts, two tutors/lecturers, one media/language expert and one graphic design expert. In the Small Group phase, there were $10^{\text {th }}$-semester PGSD undergraduate student evaluators involved in face to face tutorial meetings. Experts chosen based on their education level must be in at least five years of a doctorate. The Implementation of the research was conducted in June-December 2016 until one to one evaluation stage and small group.

\section{Introductory Phase}

- Review the module document (expert review result)

- Exploring (interviews with students, tutor, lecturers and experts)

- Deepening (observe the face to face tutorial activities of Basic Social-science concepts class subject)

- Enlightenment (attend various workshop activities and seminars regarding the evaluation of teaching materials)
- Processing (reflect various initial information and data)

- Affirmation (plan and stabilise the agreement with many respondents for conducting research)

- Design of evaluation tools: questionnaire and interviews, guidelines and exercise/quiz model.

- Planning the scheme for conducting research.

\section{One to One Phase}

From the conducting interviews, there is one student with a smart, moderate and lacking category. Data obtained in the form of initial information about the exercise/quiz quality in the module to assess material mastery. The evaluation tool used is the BMP Social Sciences Basic Concepts and interview guidelines, involving 3 PGSD undergraduate evaluators.

The triangulation of the exercise/quiz model through the results of a review of 2 material experts, two tutors/lecturers, one media/language expert and one graphic design expert

\section{Small Group Trial Phase}

- Use the exercise/quiz model of the module.

- Evaluation tools: questionnaire and interview guidelines

- Evaluators of second-semester PGSD undergraduate students amounted 8-10 in face to face tutorial meeting.

\section{Result and Discussion}

\subsection{Stage of Module Review (Preliminary Study)}

In this stage, the analysis of the module documents and the result of experts study are generated. In general, the review results of a module according to experts' material 
shows:

- The scope of the content material is too vast, somewhat overlapping and complicated, difficult for a student to understand and to master the substance in once reading. The modules are considered too heavy for undergraduate students' level. Therefore, it needs some moderation of systematic writings.

- In Module 4, the scope of material is also not explicit toward what direction of the strengthening competencies. In this case, the understanding of History knowledge structure is required in its contribution to developing powerful Social Science. We should have elaborated one by one of these concepts used in history to strengthen the IPS, in the sense of historical narrative is not required thematically.

- The depth of material is pretty deep, but because of the rising forth, back and forth quite some time, this has less depth. I think the third part is nice and deep. In contrast to the first part and the second, which is too much information crammed less systematic and convoluted writings.

\subsubsection{Level of Enlightenment}

In this stage, the enlightenment activities performed concerning the development of learning materials. Some can follow the activities of the workshop on the development of teaching materials organized by LPPM-UT with Prof. Atwi Suparman as the speaker, the module developer, and the UT faculty. Moreover, in November 2014, the FKIP - UT hosts the Scientific Appointment of National Teachers by serving a variety of long-distance learning teaching materials research. A variety of teaching material information concerning the supporting materials in developing learning materials is presented. Furthermore, it involved participants from students who also get enlightened about the quality of teaching materials at UT. In these activities, researchers and many respondents perform scientific meetings and discussing to enhance the study of the subject. Furthermore, researchers also followed the activities of academic and scholarly meetings in the ICDE conference in Bali. This occasion becomes a place to get a reference for the utilization of long-distance learning materials as the central pillar of learning for long distance education students. In this enlightening level a range of studies were obtained on the characteristics of long-distance education teaching materials, what, why, and how is the excellent teaching materials for long distance learning.

\subsubsection{Stage of Exploration}

In this stage, the authors executed an observation and observed the face-to-face tutorial activities to tutor subjects on the Social Science Basic Concept course in one of learning groups in Tangerang Area. The note evaluation when tutor presents the tutorial in the class with students become the information and preliminary data for the improvement of teaching materials. In general, students and tutors get difficulties in developing the material in the specific parts of the module, especially in module 1 and module 4 . The obstacle in understanding this module is due to the too vast conceptual material and discussed with the very minimum examples. A question and answer opportunity with students and tutors obtained information that the material presented in the module raises the flatness and fewer train students to dig deeper. The material in the module invites students always to memorize and do not train their development level of understanding.

\subsubsection{Processing Level}

At this point, researchers did a reflection of the exploring results by gathering a variety of information and preliminary data concerning the utilization of teaching materials. The results elaborated with the notes during the stage of activities. The reflection results show that utilization of teaching materials used by students put more emphasis on memorization context. Also, each learning model should apply their learning activities, which are not well realized. Furthermore, the variety of examples and non-example, which is inadequate, should become a qualified pattern module. It can be seen at some of the students who have not been successful follow the lessons well.

\subsubsection{The level of Reinforcement}

In this stage, the researcher and the students as well as the tutors do a deal to collaborate in the study. The student and tutor, as an essential component of this research, are partly responsible and fully participate as well as having a healthy attitude of obedience to excavate the desired quality of teaching materials. For gaining more basic knowledge about the implementation of the review module with tutorial activities, the researchers conducted a non-participatory observation for two months (8 times meeting in TTM at Learning Group in Tangerang). This observation raised a real deep image in the side-lines of the module in TTM activities. TTM programs are very complex, so based on the analysis of the strengths and weaknesses, gained from those students and tutors as well as facilities and infrastructure which support the quality of teaching materials that meet the good criteria, it need to be followed by the development of the better instruments to evaluate, in the form of guidance instruments and in-depth interviews.

\subsubsection{The Planning Stage of Evaluation Tools: A Questionnaire and Interview Guidelines and Exercise/Quiz Model}

At this point, researchers develop various instruments to questionnaires and interviews. Development of the instrument based on the research needs that are improvements of teaching materials especially digs on the exercise model for improvement of teaching materials. The result of instrument development and research guidelines as follows. 
Table 1. Indicators Instrument Research Reviews

\begin{tabular}{|c|c|c|c|c|}
\hline No. & Indicator & & Instrument & Experts Notes \\
\hline 1. & $\begin{array}{l}\text { The suitability of } \\
\text { exercise with the } \\
\text { material on the module }\end{array}$ & $\begin{array}{l}\text { b) } \\
\text { c) } \\
\text { d) } \\
\text { e) } \\
\text { f) }\end{array}$ & $\begin{array}{l}\text { The suitability with the completeness of the exercise } \\
\text { material } \\
\text { The suitability with the level of exercise material } \\
\text { The suitability with the depth of exercise material } \\
\text { The suitability with the accuracy of concept exercise } \\
\text { The suitability of exercise with sample accuracy } \\
\text { The suitability of exercise with the linkage concept }\end{array}$ & $\begin{array}{l}\text { Adequate to dig the material that can be } \\
\text { tailored to the needs of exercise patterns. }\end{array}$ \\
\hline 2. & Language & $\begin{array}{l}\text { d) } \\
\text { e) } \\
\text { f) } \\
\text { g) } \\
\text { h) } \\
\text { i) } \\
\text { j) }\end{array}$ & $\begin{array}{l}\text { The sentence by the rules of Indonesian } \\
\text { The sentence involves the ability to think logically } \\
\text { and critically } \\
\text { The structure of the sentence by the development of } \\
\text { student } \\
\text { The Communicative Sentence } \\
\text { Punctuation by the enhanced spelling } \\
\text { The word or term easy to read } \\
\text { The figure, tables, mosaic are easy to read } \\
\text { Physical appearance good and attractive } \\
\text { The attractiveness of the material on exercise } \\
\text { Format of the design is attractive and easy to } \\
\text { understand }\end{array}$ & $\begin{array}{l}\text { Generate enough data about the needs of } \\
\text { the quality and effectiveness of the use of } \\
\text { words/language expected in the module. }\end{array}$ \\
\hline 3. & $\begin{array}{l}\text { Pattern and Model of } \\
\text { exercise }\end{array}$ & $\begin{array}{l}\text { a) } \\
\text { b) } \\
\text { c) } \\
\text { d) }\end{array}$ & $\begin{array}{l}\text { Instructions in interactive exercises } \\
\text { Illustration images, tables, charts, and diagram } \\
\text { The Interesting and supporting exercise page } \\
\text { The model of exercise is interactive and varied }\end{array}$ & $\begin{array}{l}\text { Adequate to obtain data regarding the } \\
\text { need for exercise on the modules }\end{array}$ \\
\hline 4. & Format Measurement & $\begin{array}{l}\text { a) } \\
\text { b) }\end{array}$ & $\begin{array}{l}\text { Not interfere with the legibility process } \\
\text { Margin size by books standard. }\end{array}$ & $\begin{array}{l}\text { Adequate to obtain information related to } \\
\text { graphic design. }\end{array}$ \\
\hline
\end{tabular}

Table 2. Reflection Analysis

\begin{tabular}{|c|c|}
\hline Respondent & Reflection \\
\hline Students & $\begin{array}{l}\text { Modules or MMB (the Main Material Book) IPS, basic concept course as a whole, is quite good, although it still requires } \\
\text { some repairs and improvements to make it effective teaching materials. }\end{array}$ \\
\hline $\begin{array}{l}\text { Material } \\
\text { Experts }\end{array}$ & $\begin{array}{l}\text { The coverage of the material following the material is contained in the MMB IPS Basic Concepts course. Things need to } \\
\text { be added in this MMB are the use of appropriate learning model to study the activity of IPS at the primary level. }\end{array}$ \\
\hline Tutor (1) & $\begin{array}{l}\text { The material contained in the MMB quite fit the needs of students in learning IPS Basic Concepts course. Also, the depth } \\
\text { and breadth of this MMB material already meet the need for learning about the current concept of all IPS. }\end{array}$ \\
\hline Tutor (2) & $\begin{array}{l}\text { Learning model used in the MMB IPS basic concepts course fairly in accordance with IPS learning activities in } \\
\text { elementary school. However, it should be added an explanation of how the media can be used for learning all IPS's study. } \\
\text { It would be better if the MMB is equipped with a brief explanation of the use of methods and media that can be used in the } \\
\text { activity of all IPS's learning. }\end{array}$ \\
\hline Tutor (3) & $\begin{array}{l}\text { One of the things that is a strength in this module is the inclusion of a glossary that can help students learn the definitions } \\
\text { of the concepts being studied. The explanation made in the answer key is also very detailed and helpful in understanding } \\
\text { the questions posed in the formative tests. In addition it needs to be supplemented with real-world examples that are useful } \\
\text { for students and exercise needs to add some cases to the application of the social with the basic concepts of IPS's. }\end{array}$ \\
\hline Lectures & $\begin{array}{l}\text { Theoretically, module or MMB IPS Basic Concepts is pretty good. Also, this module also discusses the material to be } \\
\text { learned by students including the characteristics and needs of social studies education. A description of the concepts } \\
\text { expressed in the MMB IPS is quite detailed and specified. However, there are also many terms/concepts that are less clear. }\end{array}$ \\
\hline $\begin{array}{c}\text { Graphic } \\
\text { design experts }\end{array}$ & $\begin{array}{l}\text { MMB IPS Basic Concepts also has several components that need to be repaired including necessary additional } \\
\text { illustrations and charts that can help in students' understanding of the concepts being studied. }\end{array}$ \\
\hline
\end{tabular}

\subsubsection{Planning (Plan) for a Research Scheme}

The planning stage is the stage of planning the creation/innovation of focus material that has been studied by making some plans to achieve the target. At the planning stage, the researchers compiled data retrieval program agenda and interview for the respondent. The respondents involved are students who have taken IPS
Basic Concepts course, tutors, lecturers of the IPS Basic Concepts courses, learning/material expert, and printing/graphic design experts. This planning scheme produces any format research study design and analysis instruments needed. According to the results in planning stages, further, it carried the reflection of any data generated by the respondents. Here are the results of the 
analysis of reflection planning.

Furthermore, reviewing the implementation of the instrument to the respondent generated the data and sub-culture that begins with an axiom, and that is the challenge. Challenges arise from the idea, the will, and the urge to take the initiative, namely creative thinking and innovative action that can overcome and solved the initial challenges.

\subsection{Results of the Review of the One-on-one Student (One to One)}

When conducting the interviews, there is a one-on-one student with the category of smart student, moderate and less. The data obtained in the form of the initial information is about the quality of the exercises/quizzes in the modules to assess the mastery of the material. Develop tool used is MMB IPS Basic Concepts and interview guides. It engages three people of PGSD Undergraduate student as evaluators.

The results of three students in one-on-one interview shows that the diversity of response and assessment of the exercises in the module include: appropriateness of the material, pattern of the graphics display, the language used, the presented text, the clarity of the instructions in doing exercises, fitness exercises with text, and the presented exercises questions. Deepening the interview according to the students about the quality of the exercise modules are included in the category of less by achieving a percentage of $40 \%-70 \%$, so some particular parts of the exercise component need to be improved.

After giving the assessment, the three one-on-one students give advice, criticism, and commentary on the exercise in module 1 and 4 . In general, students suggested that there are five categories to improve the exercise in the module:

1. Needs of exercise for students to enrich and understand the material

2. Conformity with depth and breadth of exercise materials that have been studied in the discussion module

3. Patterns of exercise are interactive and varied ( not rigid and monotonous )

4. The language used in practice are systematic and coherent

5. Exercises equipped with direction/guidelines and graphic media that support mastery of the material

Their comments about the exercise were referring to the suitability and were quite understandable. With the variation on the display of exercise, it can motivate enrichment material and is not tedious.

\subsection{Results of the Small Group Trial (Small Group)}

4.3.1 Discussion and Analysis of Matter Expert
Based on the analysis results obtained from the expert on the module content, it can be seen that the matter experts provide an assessment of the quality of materials include: compliance with the completeness of the training material, the breadth of the material, the depth of the material, the accuracy of the concept the accuracy of the example, and the linkage concept. Matter experts stated in the recommendation section, that the quality of the materials developed in modules 1 and four, as well as the suitability of the material with exercises/quiz, had been prepared which shows a pattern adapted to the purposes of measurement of low-level cognitive achievement through essay questions. However, the critical and creative thinking lack accommodated, especially if we want to measure the attitude domain and psychomotor aspects, we must use the interactive and varied observation forms/ process/ performance, and others proper ways.

\subsubsection{Revision Level}

At the stage of the model revision of exercises/quiz material performed by two experts, two tutors/lecturers, one student, and one graphic design, the results of the model revision of exercises/quizzes largely showed good condition and are incomprehensible. The students understand almost $78 \%$ of the pattern. In the pattern for the category descriptions, some trouble is more varied than the simple format pattern to fill it. There needs to be an explanation of the statement, which is easy to learn, and the column is more straightforward than before. The change from the usual format contained in the module with a diverse practice model resulted in a pattern that must be adapted to the character of the students who had been had. In the columns, which are too much should be adapted to the capacity of memory and observation of students towards the subject. For example, for a column that is not contained in the module becomes an essential part of the model of exercise/quiz. Similarly, the row numbers are described in detail and simple, not confusing. Several general studies about the revision are as follows:

\footnotetext{
Every format has been revised and includes the thematic title following the subject of discussion in the module.

- The revised format in the original column consists of 3 columns to 2 columns. (see attachment). This is because it is more modest and straightforward.

- Exercises/quizzes included multiple indicators as signposts to facilitate students in analyzing the state of previous student knowledge.

- The numbers are written in simple way and described systematically to avert confusing.
}

The pictorial material should be improved and simplified. 
Table 3. Model of Exercise/Quiz in Module of Modification Result

\begin{tabular}{|c|c|c|}
\hline $\begin{array}{c}\text { MODULE/ } \\
\text { SUBJECT OF } \\
\text { DISCUSSION }\end{array}$ & CONCEPT & MODEL OF EXERCISE \\
\hline $\begin{array}{l}\text { Module } 1 \\
\text { The Nature and } \\
\text { Characteristics of } \\
\text { Social Studies } \\
\text { Basic Concept } \\
\text { Course. }\end{array}$ & $\begin{array}{l}\text { The nature of Basic Concepts Social } \\
\text { Studies Course, include: } \\
\text { - Social Studies is a field assessment } \\
\text { of symptoms and social problems. } \\
\text { - Social Studies framework does not } \\
\text { emphasize the theoretical plane, but } \\
\text { in the practical field in the study of } \\
\text { symptoms and social problems that } \\
\text { are in the community. }\end{array}$ & $\begin{array}{l}\text { In the picture below, the children were interacting with the surrounding } \\
\text { environment. While playing they identify their social environment as } \\
\text { well as individual learning in a pluralistic society, children learn about } \\
\text { social phenomena and equip themselves with the experience of } \\
\text { cognitive, affective and psychomotor to everyday life. }\end{array}$ \\
\hline $\begin{array}{l}\text { Module } 2 \\
\text { The Scope and } \\
\text { Coverage of } \\
\text { Social Studies } \\
\text { Basic Concept. }\end{array}$ & $\begin{array}{l}\text { Relationship of Social Science Basic } \\
\text { Concepts with the Sain, Teknologi, dan } \\
\text { Masyarakat (Science, Technology, } \\
\text { Society) scope. } \\
\text { a. History, the discussion is aimed at } \\
\text { life and human life in the context of } \\
\text { social. } \\
\text { Geography - the study of the } \\
\text { similarities and differences of } \\
\text { geosphere phenomenon with an } \\
\text { environmental standpoint or } \\
\text { territoriality in a spatial context. } \\
\text { Economic and cooperative, } \\
\text { scientific studies on how human } \\
\text { material needs. } \\
\text { d. Sociology studied in the context of } \\
\text { human social interaction. } \\
\text { e. Anthropology is a study of human } \\
\text { social behavior or culture. } \\
\text { f. Politics and Government, the study } \\
\text { of the life of the country, studying } \\
\text { the state do its job reaching certain } \\
\text { objectives following the duties, } \\
\text { powers as state officials, the power } \\
\text { to rule the country. } \\
\text { g. Social Psychology, the scientific } \\
\text { study of human mental processes as } \\
\text { social beings. }\end{array}$ & $\begin{array}{l}\text { Picture. Entanglement between the Science of Technology Society and } \\
\text { Social Studies (Science and Society Committee, 1989) } \\
\text { From the diagram, it can be explained that science, technology, and } \\
\text { society is a circuit or system that has a close connection with one } \\
\text { another, and the social studies position may explain the science, } \\
\text { technology, and society by the information found on these three } \\
\text { elements either a negative or positive impact. Understanding of the } \\
\text { concept of science, technology, and society can be bridged through a } \\
\text { learning process that integrated social studies. }\end{array}$ \\
\hline
\end{tabular}




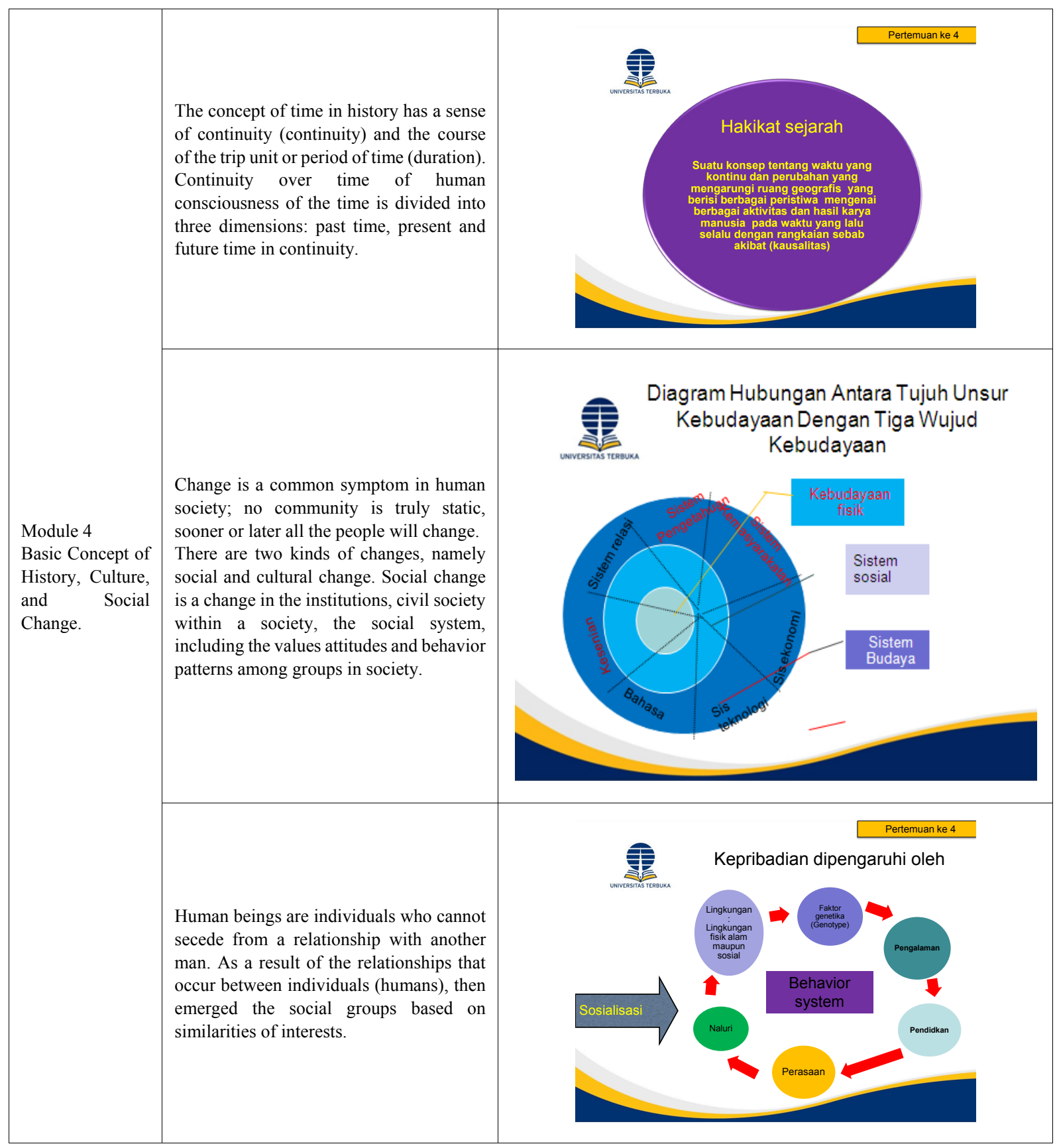

Based on the results of the student questionnaire, it is known that a small group of overall test percentage earned on average in almost every item by $85-90 \%$ expressed appropriately. These results are included in good criteria. In general, students suggested that exercise in the module improved includes five categories. These include: a) The need for students to practice and understanding of the material enrichment.; b) Compliance with the depth and breadth of exercise materials that have been studied in the discussion module; c) The interactive and varied exercises pattern (not rigid and monotonous); d ) The language used in practice systematic and coherent; e) Exercise equipped with direction/guidelines and graphic media that supports mastery of the material. Recommendations of this research are Undergraduate program that can attempt to produce a wide range of innovations product in the learning module. UT Lecturer can implement a variety of teaching materials from PJJ research results, and PGSD Undergraduate Teachers/Students can take advantage of this type of exercise/quiz as an alternative mastery of the material.

A meta-analysis of Levie and Lentz [16] who reviewed 51 comparative studies found that 41 of the whole comparisons indicated a significant advantage for text accompanied by images. Meanwhile, Levin, Bender and Lesgold [17] found that verbal explanation with the picture made a better contribution to performance. Mayer and Sims [18] found that the appearance of images and words combined simultaneously during learning can improve the 
ability to construct the relationship between verbal information and visual information.

Badang [19] argued that critical thinking is gaining renewed attention and endorsement while typical patterns of social studies classroom practice appear less conducive to critical thought. To develop the critical thinking in learning social studies education, it is necessary to implement exercises that later can be used to direct essential thinking skill for students; this exercise must be conducted continuously, intensively, and programmed, with the training system. In the end, students will be trained to express their thoughts systematically and practically.

The questions on the document/photo analysis worksheet or learning exercises help students to practice social phenomenon thinking skills, and make the students learn in the second tradition of Social Sciences (Barr, 1980). The research about teaching materials conducted by the writer Padmo and Suhartono [20] shows that the appearance of exercises in various modules is more able to motivate students to enrich the material and is not boring.

\section{Conclusions}

Based on the analysis of the model development exercises/quiz on the module /MMB IPS Basic Concepts course, some conclusions are as follows: the model pattern of exercises/quiz is developed through three steps of research, namely the review of preliminary, one-on-one test, and test a small group (small group). The application is based on a learning approach as a system (input - process - output) consisting some inter-functionality components to achieve goals, relating to the model to generate the design implementation - evaluation and follow-up. Exercises developed is referring to the suitability and quite understandable. The presence of varied display of exercises will be able to motivate for enrichment material and not tedious. Based on the results of the student questionnaire, it is known that a small group of overall test percentage earned almost average on every item at $85-90 \%$ expressed that the model exercises/quizzes are developed accordingly. These results are included in both criteria.

In general, students suggested that exercise in the module improved includes five categories. These include: a) The need for students to practice and understanding of the material enrichment; b) Compliance with the depth and breadth of exercise materials that have been studied in the discussion module; c) The interactive and varied exercises pattern (not rigid and monotonous); d ) The language used in practice systematic and coherent; e) Exercise equipped with direction/guidelines and graphic media that supports mastery of the material. Recommendations of this research are Undergraduate program that can attempt to produce a wide range of innovations product in the learning module; UT Lecturer can implement a variety of teaching materials from PJJ research results, and PGSD Undergraduate Teachers/Students can take advantage of this type of exercise/quiz as an alternative mastery of the material. These findings can be used as one essential consideration to design, make or arrange module for the module developers.

\section{REFERENCES}

[1] Darmayanti, T., Rachmatini, M., and Karim, F.: 'Studi jangka panjang tentang efektivitas intervensi psikologis dalam meningkatkan kemampuan belajar mandiri dan prestasi belajar mahasiswa pendidikan jarak jauh', Jurnal Pendidikan Terbuka dan Jarak Jauh, 2011, 12, (1), pp. 01-18

[2] Jalil, A.: 'Pendidikan Jarak Jauh', Jurnal Ilmu Pendidikan Universitas Negeri Malang, 2009, 1, (1)

[3] Julaeha, and Pratmoko: 'Pengembangan Bahan Ajar' (PAU-PPAI., 2004. 2004)

[4] Ellington, H.: 'Producing teaching materials: A handbook for teachers and trainers' (1993. 1993)

[5] Duman, B.: 'Self Assessments of the Prospective Teachers about the Teaching Materials They Have Designed', World Journal of Education, 2018, 8, (6), pp. 165-175

[6] Stronge, J.H.: 'Qualities of effective teachers' (ASCD, 2018. 2018)

[7] Chen, J., Wang, M., Kirschner, P.A., and Tsai, C.-C.: 'The role of collaboration, computer use, learning environments, and supporting strategies in CSCL: A meta-analysis', Review of Educational Research, 2018, 88, (6), pp. 799-843

[8] Michel, N., Cater III, J.J., and Varela, O.: 'Active versus passive teaching styles: An empirical study of student learning outcomes', Human resource development quarterly, 2009, 20, (4), pp. 397-418

[9] Corter, J.E., Esche, S.K., Chassapis, C., Ma, J., and Nickerson, J.V.: 'Process and learning outcomes from remotely-operated, simulated, and hands-on student laboratories', Computers \& Education, 2011, 57, (3), pp. 2054-2067

[10] Lee, S.J., Srinivasan, S., Trail, T., Lewis, D., and Lopez, S.: 'Examining the relationship among student perception of support, course satisfaction, and learning outcomes in online learning', The internet and higher education, 2011, 14, (3), pp. 158-163

[11] Spronken-Smith, R., Walker, R., Batchelor, J., O'Steen, B., and Angelo, T.: 'Evaluating student perceptions of learning processes and intended learning outcomes under inquiry approaches', Assessment \& Evaluation in Higher Education, 2012, 37, (1), pp. 57-72

[12] Degeng, I.N.S., and Sudana, N.: 'Ilmu pengajaran taksonomi variabel', Jakarta: Depdikbud, 1989

[13] Bruner, J.S.: 'The process of education' (Harvard University Press, 2009. 2009)

[14] Morrison, G.R., Ross, S.M., Kalman, H.K., and Kemp, J.E.: 'Designing Effective Instruction' (Wiley, 2012. 2012) 
[15] Dick, W., and Carey, L.: 'The systematic design of instruction', in Editor $(\text { Ed. })^{\wedge}($ Eds.): 'Book The systematic design of instruction' (2005, edn.), pp.

[16] Levie, W.H., and Lentz, R.: 'Effects of text illustrations: A review of research', Ectj, 1982, 30, (4), pp. 195-232

[17] Levin, J.R., Bender, B.G., and Lesgold, A.M.: 'Pictures, repetition, and young children's oral prose learning1', AV Communication Review, 1976, 24, (4), pp. 367-380

[18] Mayer, R.E., and Sims, V.K.: 'For whom is a picture worth a thousand words? Extensions of a dual-coding theory of multimedia learning', Journal of educational psychology, 1994, 86, (3), pp. 389

[19] Badang, G.G.: 'Perspectives on Teacher Decision-Making on Social Studies in Cameroon', The Ohio State University, 2013

[20] Padmo, D.A., and Suhartono: 'The Use of Teachers Communication Forum Through an Open Educational Resource in Indonesia', 2013 